\title{
Response of Understory Species Following Herbicidal Control of Low Sagebrush ${ }^{1}$
}

\author{
RICHARD E. ECKERT, JR., ALLEN D. BRUNER, \\ AND GERARD J. KLOMP2
}

Range Scientist, Plant Science Research Division, Agricultural Research Service, U.S. Department of Agriculture; Junior Range Ecologist, Nevada Agricultural Experiment Station, University of Nevada; and Range Scientist, Plant Science Research Division, Agricultural Research Service, U.S. Department of Agriculture, Reno, Nevada.

\section{Highlight}

Control of low sagebrush in northern Nevada increased productivity of understory grass species. On fair condition sites, climax dominant species such as Idaho fescue, bluebunch wheatgrass, and Thurber needlegrass gave a yield response but the response was not obtained for 2 years after treatment. How. ever, the rapid response of Sandberg bluegrass resulted in a significant total perennial grass response the year after treatment. On poor condition sites, squirreltail gave a smaller response and the response was not obtained for 2 to 4 years after treatment. Dense stands of annual species gave a large yield response the year after treatment and suppressed the response of squirreltail. Scattered stands of annuals did not respond until 4 years after treatment. Soil moisture relations explained differences in total yield. However, differences in early spring growth were attributed to soil nitrogen.

Low sagebrush species (Artemisia arbuscula and $A$. longiloba) are found on approximately 28 million acres in the western United States (Beetle, 1960). This acreage represents about one-tenth of the total sagebrush type. Ecological aspects of low sagebrush and associated soils have been studied (Eckert, 1957; Passey and Hugie, 1962; Tueller, 1962; Robertson et al., 1966; Zamora, 1968; and Summerfield, 1969). However, range improvement research in this type is limited. Eckert and Evans (1968) evaluated herbicidal control of low

${ }^{1}$ Contribution from the Plant Science Research Division, Agricultural Research Service, U.S. Department of Agriculture and the Nevada Agricultural Experiment Station, University of Nevada, Journal Series No. 194. Received August 16, 1971.

2 The authors gratefully acknowledge the cooperation of the Bureau of Land Management, U.S. Department of the Interior for land and fencing; L. N. Langen, Soil Conservation Service, U.S. Department of Agriculture, Portland, Oregon for soil descriptions and interpretations; and Dr. Gary V. Richardson, Agricultural Research Service, U.S. Department of Agriculture, Fort Collins, Colorado for statistical services. sagebrush and speculated that sites with an understory of bluebunch wheatgrass (Agropyron spicatum), Idaho fescue (Festuca idahoensis), or Thurber needlegrass (Stipa thurberiana) may have potential for increased forage production after brush control. This paper describes the understory response obtained.

\section{Methods}

This study was conducted at nine locations in northern Nevada from 1964 through 1970. Elevation and precipitation extremes ranged from 5000 to $7300 \mathrm{ft}$ and from 10 to 15 inches, respectively. Low sagebrush was sprayed with propylene glycol butyl ether esters of (2,4-dichlorophenoxy) acetic acid (2,4-D) in May and June, 1963 and 1964. Brush control ranged from 96-100\%. Plots were 20 by $20 \mathrm{ft}$ in a randomized block design with three or four replications.

Vegetation changes after brush control were evaluated by plant frequency (Hyder et al., 1963). On treated and check plots, five transects of five quadrats cach were sampled the year of treatment and 5 years later. Quadrat size was 7.5 by 7.5 inches for Sandberg bluegrass (Poa secunda) and annual species, 15 by 15 inches for squirreltail (Sitanion hystrix), and 30 by 30 inches for other grasses, forbs, and shrubs.

Perennial grass production was determined each July on two $20-\mathrm{ft}^{2}$ subplots in each main plot. Production of annuals was determined on one $20-\mathrm{ft}^{2}$ subplot. Subplots were rotated so that the same areas were not clipped more often than once in 3 years. After 3 years, no effect of previous clippings was observed. Only herbaceous species are represented in production data.

An attempt was made to determine some reasons for yield responses measured. Gypsum soil moisture blocks were buried in treated and check plots at five sites in 1964. One block was at 6 inches, one in the $\mathbf{B}_{2}$ horizon (approximately 12 inches), and one in the $B_{3}$ horizon (17 to 34 inches). Readings made in spring and summer of 1964 to 1970 were converted to bars of soil moisture tension. Herbage of dominant grass species was harvested in April, May, and June of 1968 and 1969 to quantify an early spring growth response observed. On each date, soil moisture blocks were read. Soil samples from the 0-3, 3-6, and 6-12-inch depths were collected and analyzed for $\mathrm{NO}_{3}-\mathrm{N}$ by the phenoldisulfonic acid method (Chapman and Pratt, 1961). Herbage was analyzed for nitrogen by the micro-Kjeldahl method.

Data were analyzed by the analysis of variance and treatment means were compared by Duncan's Multiple Range Test. Probability of $<.05$ was accepted as significant.

Vegetation at three locations was classified into three distinct and different habitat types: low sagebrush/bluebunch wheatgrass (Duck Creek); low sagebrush/Idaho fescue (Dobe Summit); and low sagebrush/ Thurber needlegrass (Bishop Flat). Soil was described and classified according to Soil Taxonomy (USDA, 1970). 
Table 1. Production of perennial grass and annual species (lb./acre) on treated and check plots at two locations for the period 1964 to 1970. Plots were treated in 1963 .

\begin{tabular}{|c|c|c|c|c|c|c|}
\hline \multirow[b]{3}{*}{ Date } & \multirow{2}{*}{\multicolumn{2}{|c|}{$\frac{\text { Dobe Summit }}{\text { Perennial grass }}$}} & \multicolumn{4}{|c|}{ Silver Creek } \\
\hline & & & \multicolumn{2}{|c|}{ Perennial grass } & \multicolumn{2}{|c|}{ Annuals } \\
\hline & Treated & Check & Treated & Check & Treated & Gheck \\
\hline 1964 & 431a $x y^{1}$ & $86 \mathrm{~b} \times$ & $29 \mathrm{a} \times$ & $10 \mathrm{a} x$ & $201 \mathrm{a} \mathrm{w}$ & $34 b \times$ \\
\hline 1965 & $331 \mathrm{la} x$ & $77 \mathrm{~b} \times$ & $43 a x$ & $34 \mathrm{a} \times$ & $264 a$ wy & $67 b \times$ \\
\hline 1966 & $489 \mathrm{a} y$ & $163 \mathrm{~b} \times$ & $123 a x y$ & $19 \mathrm{~b} \times$ & $163 \mathrm{a} w$ & $77 \mathrm{a} \times$ \\
\hline 1967 & $498 \mathrm{a} y$ & $153 \mathrm{~b} \times$ & $163 \mathrm{a} y$ & $67 \mathrm{~b} \times$ & $249 a w x$ & $235 a$ y \\
\hline 1968 & $633 \mathrm{a} \mathrm{z}$ & $129 \mathrm{~b} \times$ & $230 \mathrm{a}$ y & $81 \mathrm{lb} x$ & $316 a$ wxy & $72 \mathrm{~b} \times$ \\
\hline 1969 & $537 a y z$ & $153 \mathrm{~b} \times$ & $163 a y$ & $77 \mathrm{~b} \times$ & $403 \mathrm{a} \mathrm{yz}$ & $48 b \times$ \\
\hline 1970 & $479 \mathrm{a} y$ & $192 \mathrm{~b} \times$ & $153 a y$ & $81 b \times$ & $479 \mathrm{a} \mathrm{z}$ & $91 b \times$ \\
\hline
\end{tabular}

1 Means within location are compared between treatments and among years. Means followed by the same letter ( $a$ or b) in horizontal sequence or by the same letter ( $w$ through $\mathrm{z}$ in vertical sequence are not significantly different at the .05 probability level as determined by Duncan's Multiple Range Test.

\section{Results and Discussion}

Site Potential and Range Condition

Species composition, soil characteristics, and total productivity suggest that although the Duck Creek and Dobe Summit sites represent different habitat types they are similar in productive potential and the highest potential sites studied. On the same basis, Bishop Flat is a different habitat type with a lower productive potential. On five sites (such as Silver Creek), low seral condition precluded an interpretation of habitat type or productive potential. These four sites represent the range in characteristics found on all nine sites studied, c.g. sites with different climax dominant grass species; sites with very few or no climax dominant grass species; and sites with and without an understory of annual species. In tabular presentation, data from Dobe Summit (Table 1) characterize the response on those sites with a fair stand of climax dominant grasses. Data from Silver Creek (Table 1) characterize the response on those sites with very few or no climax dominant grasses but with an understory of squirreltail and annuals.

Soil morphology and root distribution suggest a reason for differences in productive potential.
Soils at Duck Creek and Dobe Summit have clay loam to light clay textured B horizons, weak to moderate angular and subangular blocky structure, and roots at 20 to 30 inches. Soils at Bishop Flat and Silver Creek have heavy clay B horizons, abrupt textural change between the $\mathrm{A}$ and $\mathrm{B}$ horizons, strong columnar and strong subangular blocky structure, and very few inped roots below 9 to 12 inches. Apparently structure of the montmorillonitic clay B argillic horizon can effectively limit rooting depth and, therefore, productivity. Summerfield (1969) reported that the zone of inped rooting in claytextured $B$ horizons determined the distribution of low sagebrush and big sagebrush (A. tridentata). White and Lewis (1969) showed that certain native grass species do not grow on Dense Clay Range soils presumably because roots are not adapted to the constricting and stretching forces in these soils.

Range condition at time of treatment was not determined quantitatively. However, judgement of condition was based on productivity of relict low sagebrush sites in Idaho (Passey and Hugie, 1962) and on frequency data from very good low sagebrush sites in Nevada (Zamora, 1968). Silver Creek was considered to be in very poor condition at time

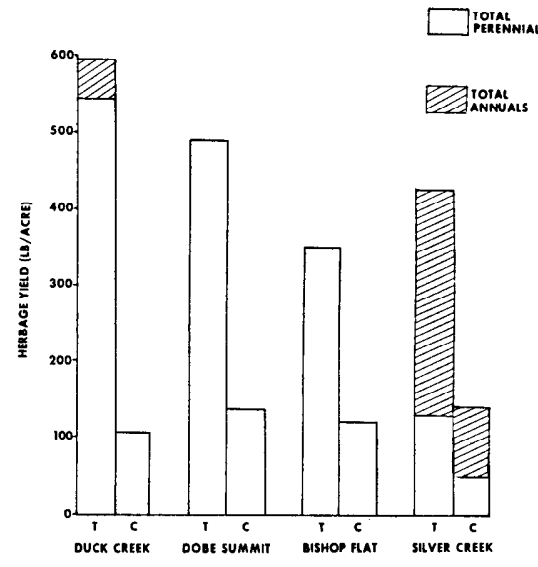

FIG. 1. Average herbage yield for treated (T) and check (C) treatments for a 6year period at Duck Creek and a 7-year period at the other locations.

of treatment due to lack of climax dominant grass species, and an abundance of native and alien annuals such as cheatgrass (Bromus tectorum), six-weeks fescue (Festuca octoflora), and species of Cryptantha, Gayophytum, Polygonum, and Eriastrum. Duck Creek, Dobe Summit, and Bishop Flat were judged in fair condition at time of treatment. No annual species were found at the latter two sites. Frequency of climax dominant grasses the year of treatment was: bluebunch wheatgrass at Duck Creek59\%; Idaho fescue at Dobe Summit $-44 \%$; and Thurber needlegrass at Bishop Flat-66\%.

\section{Production and Frequency}

Check plot yields (Fig. 1) indicate that brush competition severely suppressed the understory and restricted expression of potential grass productivity. For example, average check grass yield at Duck Creek was $105 \mathrm{lb}$./acre with an average annual precipitation of 15 inches. Check yield at Bishop Flat was $120 \mathrm{lb}$./acre with an average precipitation of only 11 inches.

Control of low sagebrush resulted in a significant increase in yield of perennial grasses, annuals, and total productivity (Fig. 1). On treated and check plots, average lb./acre yields were: perennial grasses-313 and 92 ; annuals- 123 and 51 ; and 


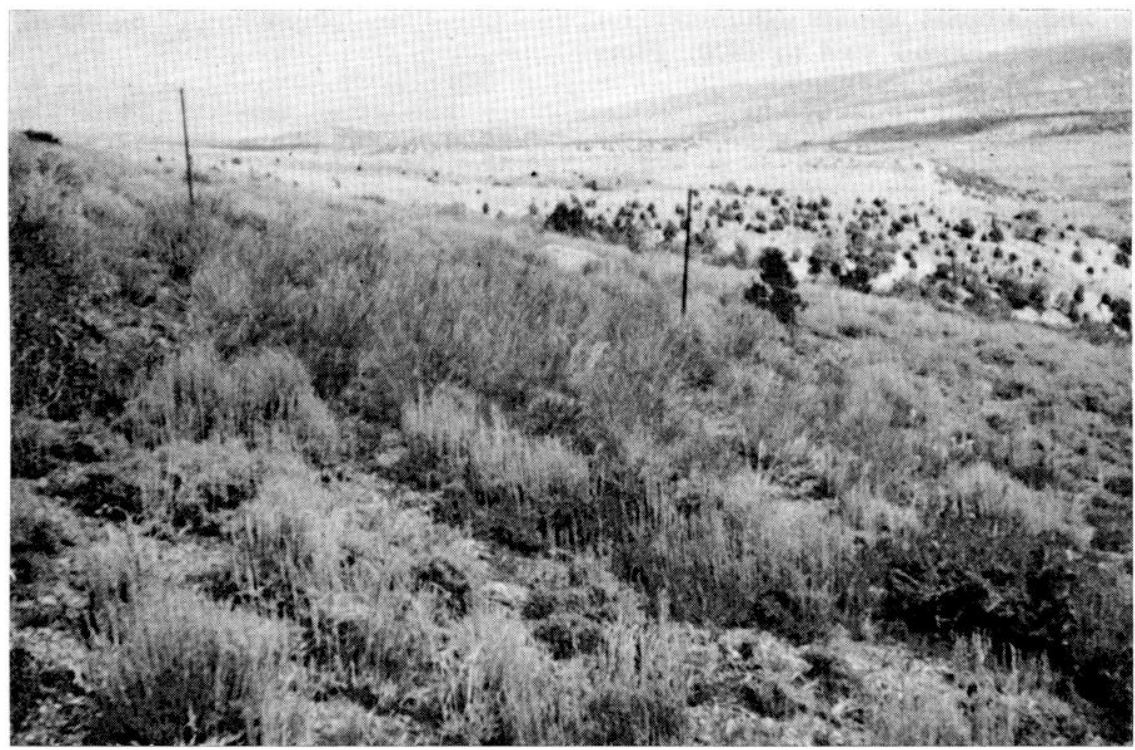

Fig. 2. Bluebunch wheatgrass response at Duck Creek in 1968. Low sagebrush control plot, background between two posts, produced 393 lb./acre. Untreated area, foreground, produced $24 \mathrm{lb}$./acre.

total production-436 and 143 , respectively. Total yield response and response of climax perennial grasses were greatest on high potential sites in fair condition. Greatest response of annuals was on sites in poor range condition.

All perennial grass species responded to brush control. Bluebunch wheatgrass at Duck Creek increased $347 \mathrm{lb}$./acre over the period of study. At Dobe Summit, Idaho fescue increased $124 \mathrm{lb}$./acre; bluebunch wheatgrass 48 lb./acre; thickspike wheatgrass (Agropyron dasystachum) 81 lb./acre; and squirreltail 86 lb./acre. At Bishop Flat, Thurber needlegrass increased $92 \mathrm{lb}$./acre and squirreltail $96 \mathrm{lb}$./ acre. Squirreltail increased 67 lb./ acre at Silver Creek. Sandberg bluegrass responded differently. On low condition sites, between widely spaced plants of squirreltail, Sandberg bluegrass production increased slowly but significantly with time; for example, from $19 \mathrm{lb}$./acre in 1964 to $125 \mathrm{lb}$./acre in 1970. On sites with a high frequency of climax bunchgrasses, production of Sandberg bluegrass was significantly higher the year after spraying than in any year thereafter; for example, $158 \mathrm{lb}$./acre in 1964 and $10 \mathrm{lb}$./acre in 1970. Evidently this species responds to release from competition more rapidly than the climax bunchgrasses (which were probably in low vigor). As these bunchgrasses assume dominance, Sandberg bluegrass is suppressed.

Brush control resulted in a significant increase in total perennial grass production the first year after treatment and each year thereafter at Dobe Summit (Table 1) and at Bishop Flat. The climax dominant grass did not respond the year after treatment. However, the vigorous response of Sandberg bluegrass contributed to the significant total perennial grass response at both locations. A significant response was not obtained until the second year after treatment at Duck Creek because bluebunch wheatgrass did not respond the first year and because few subdominant, quick responding grasses such as Sandberg bluegrass were present. Brush control resulted in a significant yield response by bluebunch wheatgrass at Duck Creek the second and subsequent years (Fig. 2). On poor condition sites a significant perennial grass response was not obtained until the second to fourth year after treatment (Table 1). This slow response was due to low vigor of perennial species and to competition from annuals.

Total perennial grass yield on treated plots varied with year (Table 1), generally in response to time and amount of precipitation. For example, high production in 1968 at Dobe Summit was related to total yearly precipitation 1 inch below normal but with 3 inches from May 27 to June 17. Total perennial grass yield as Silver Creek increased from 1964 to 1966 on treated plots then remained constant, possibly due to generally increasing competition from annuals. On the check, total perennial grass production did not vary with year at any location due to brush suppression.

On sites with a dense but suppressed population of annuals, brush control resulted in a large increase in production by annuals the year following treatment (Table 1). Scattered stands of annuals on low condition sites did not show a significant yield response until 4 years after treatment. Production by annuals on check plots did not vary except in years of above average or heavy spring precipitation such as 1967 at Silver Creek. Precipitation that year was 1 inch above average with 2.4 inches after May 1.

The only important perennial forbs were big-head clover (Trifolium macrocephalum) and Crag aster (Aster scopulorum). Both species were injured by 2,4-D treatment. Frequency of big-head clover in 1968 averaged 48 and $1 \%$ on check and treated plots, respectively. Respective yields in 1970 were 24 and $1 \mathrm{lb}$./acre. Crag aster was not harvested, but 1970 frequency was $60 \%$ on the check and $14 \%$ on treated plots.

At Dobe Summit, Idaho fescue comprised 20 and $15 \%$, respectively, of the total yield on treated and check plots in 1964. In 1970, this species comprised 42 and $47 \%$ of the yield, respectively. During the same period, squirreltail composition dropped from 38 to $18 \%$ on 
the treated plots but remained constant on the check. At Bishop Flat, Thurber needlegrass comprised 4 and $2 \%$, respectively, of the total yield on treated and check plots in 1964. In 1970, this species comprised 48 and $38 \%$ of the yield. Composition of squirreltail at Bishop Flat was high, 33 and $44 \%$, on the treated and check plots in 1964 and remained high, 29 and $45 \%$, respectively, in 1970 . Bluebunch wheatgrass made up nearly $100 \%$ of the yield at Duck Creek and squirreltail made up most of the perennial grass yield on all poor condition sites. Therefore, composition of these two species was constant throughout the study.

Frequency data showed a similar trend from 1963 to 1968 . Frequency of bluebunch wheatgrass at Duck Creek remained constant on the check but increased from 59 to $72 \%$ with brush control. Frequency of Idaho fescue at Dobe Summit increased slightly on the check but increased from 44 to $65 \%$ with treatment. Frequency of Thurber needlegrass at Bishop Flat decreased from 60 to $46 \%$ on the check, but remained constant at $67 \%$ on treated plots. At Bishop Flat with squirreltail subdominant to Thurber needlegrass, squirreltail frequency decreased from 54 to $41 \%$ on the check and increased from 44 to $65 \%$ on treated plots. On low condition sites with squirreltail dominant and a sparse stand of annuals, frequency of this species remained constant on the check at an average of $32 \%$. After brush control, frequency of this species increased to an average of $54 \%$. On low condition sites with a dense stand of annuals, frequency of squirreltail did not change during the course of the study on either treated or check plots. Where Idaho fescue was dominant, squirreltail frequency was static on the treated plots but decreased from 44 to $31 \%$ on the check.

\section{Soil Moisture and Nitrogen}

Diffcrent precipitation totals and distribution patterns at Bishop Flat

Table 2. Herbage yield (lb./acre) of Idaho fescue and squirreltail at Dobe Summit on treated and check plots on three dates in 1968 and 1969; and nitrogen recovered (lb./acre) from Idaho fescue and squirrel-tail combined. Plots were treated in 1963.

\begin{tabular}{|c|c|c|c|c|c|c|}
\hline \multirow[b]{2}{*}{ Date } & \multicolumn{2}{|c|}{ Idaho fescue } & \multicolumn{2}{|c|}{ Squirreltail } & \multicolumn{2}{|c|}{ Nitrogen } \\
\hline & Treated & Check & Treated & Check & Treated & Check \\
\hline $5 / 1 / 68$ & $102 a^{1}$ & $8 b$ & $32 a$ & $22 a$ & $2.1 \mathrm{a}$ & $0.5 b$ \\
\hline $5 / 28 / 68$ & $149 \mathrm{a}$ & $64 b$ & $55 a$ & $12 \mathrm{a}$ & $2.6 \mathrm{a}$ & $0.9 \mathrm{~b}$ \\
\hline $6 / 20 / 68$ & $313 a$ & $10 \mathrm{~b}$ & $70 a$ & $48 a$ & $3.4 \mathrm{a}$ & $0.6 \mathrm{~b}$ \\
\hline $4 / 28 / 69$ & $182 a$ & $76 a$ & $78 a$ & $48 a$ & $5.2 \mathrm{a}$ & $2.7 \mathrm{~b}$ \\
\hline $5 / 12 / 69$ & $265 a$ & $38 \mathrm{~b}$ & $174 a$ & $54 \mathrm{~b}$ & $8.9 \mathrm{a}$ & $1.6 \mathrm{~b}$ \\
\hline $5 / 26 / 69$ & $325 a$ & $62 \mathrm{~b}$ & $117 a$ & $49 b$ & $7.3 \mathrm{a}$ & $1.3 \mathrm{~b}$ \\
\hline
\end{tabular}

1 Treatment means by dates are compared within species and nitrogen. Means followed by the same letter in horizontal sequence are not significantly different at the .05 probability level as determined by Duncan's Multiple Range Test.

in 1967 and 1968 resulted in soil moisture variations. Therefore, we could evaluate the effects of these variations on herbage yield by year and by treatment. Production on treated plots was $294 \mathrm{lb}$./acre more in 1967 than in 1968. In 1967, soil moisture tension did not exceed 4.0 bars to depths of 30 inches until after harvest in July. In 1968, however, moisture tension at 30 inches was above 15 bars throughout the spring and summer, and tension at 12 inches was above 15 bars on July 1 .

The effect of brush control treatment was evident in 1968. Production of perennial grasses was 200 lb./acre more on treated plots. Again, soil moisture appears important. Until May 28, moisture tensions were similar on treated and check plots. On June 18, tension at 12 inches on the check was above 15 bars, but did not exceed 8 bars on treated plots. By July 11 , tensions at 6,12 , and 30 inches on the check were well above 15 bars. On treated plots, tensions at 12 and 30 inches were also above 15 bars, however, at 6 inches moisture tension was only 0.4 bar. Precipitation of 2.5 inches in June wet the soil to a depth of between 0 and 12 inches. Soil moisture was rapidly utilized by brush and grass on the check, but was available longer for grass production on treated plots.

Soil moisture tensions on treated and check plots in April and May were similar at all locations each year after brush control. However, Idaho fescue at Dobe Summit produced more herbage on treated plots by May 1, 1968 and by May 12, 1969 (Table 2). Where dominant, bluebunch wheatgrass gave a growth response by May 1, 1968 and by April 28, 1969. Thurber needlegrass at Bishop Flat did not give an early spring response in either year. Squirreltail, as a subdominant to either Idaho fescue or Thurber needlegrass, did not respond on the earliest date but did respond by the middle of May in one year. On low condition sites, neither squirreltail, as the dominant species, nor Sandberg bluegrass gave an early spring growth response.

Hyder and Sneva (1956) and Hedrick et al. (1966) suggest the importance of competitive use of soil nitrogen to explain the total herbage response obtained after control of big sagebrush. Soil nitrogen may also explain an early spring response after brush control.

Eckert et al. (1970) found $\mathrm{NO}_{3}-\mathrm{N}$ accumulation in fallowed big sagebrush soil as early as February. However, low sagebrush soil samples collected during the spring generally showed no significant difference in $\mathrm{NO}_{3}-\mathrm{N}$. The exception was Duck Creek where, in the 0-12inch depth, respective $\mathrm{NO}_{3}-\mathrm{N}$ levels on May 1 and May 28, 1968 on treated plots were 3.7 and $3.0 \mathrm{lb}$./ 
acre compared to $1.5 \mathrm{lb}$./acre on both dates on the check. In May, $1969 \mathrm{NO}_{3}-\mathrm{N}$ was significantly greater on the treated plot $(8.0$ lb./acre) than on the check (3.2 lb./ acre). Instead of accumulating, $\mathrm{NO}_{3}-\mathrm{N}$ could also be immobilized in plant tissue or lost.

Nitrogen in grass samples from treated and check plots did not vary significantly due to treatment, species, or date in either 1968 or 1969 , however, some trends were evident. Herbage from treated plots generally had a higher percent $\mathbf{N}$ than did herbage from the check. During late April and early May, squirreltail had a higher nitrogen content than did Idaho fescue or Thurber needlegrass.

Nitrogen recovery was calculated from species yield and percent N. On poor condition sites the amount of nitrogen recovered from treated and check plots did not vary significantly. IIowever, on sites in better condition such as Dobe Summit, significantly more nitrogen was recovered from treated plots than from the check (Table 2). Calculations for bluebunch wheatgrass at Duck Creek showed respective nitrogen recovery from treated and check plots of 2.8 and $0.8 \mathrm{lb}$./ acre on April 28; 4.0 and $1.6 \mathrm{lb}$./ acre on May 12; and 7.5 and 1.8 lb./acre on May 26, 1969. Respective nitrogen recovery from Thurber needlegrass and squirreltail on treated and check plots at Bishop Flat was 4.4 and 2.7 lb./ acre, 7.1 and $3.1 \mathrm{lb}$./acre, and 2.9 and $1.4 \mathrm{lb}$./acre on the same dates. Evidently the $\mathrm{NO}_{3}-\mathrm{N}$ mineralized is utilized rapidly by grass on treated plots and by grass and brush on checks. On treated plots, $\mathrm{NO}_{3}-\mathrm{N}$ was not competitively used by brush and more was available for early spring grass production as well as for total yearly production. No yield response on check plots indicates competitive use of nitrogen by low sagebrush with less available to grass for early spring growth or for total production. Sneva et al., (1958) obtained a similar response with crested wheatgrass. They found that grass growth prior to June 1 was seldom restricted by soil moisture, but by low temperature and limited soil nitrate. Additional soil nitrogen accelerated spring growth, increased total production, and improved water use efficiency.

The amount of nitrogen recovered in the forage may not account for all the $\mathrm{NO}_{3}-\mathrm{N}$ mineralized. Waterlogged soil conditions in early spring would be conducive to losses from denitrification under anaerobic conditions, leaching, and runoff. In addition, forbs and minor grasses were not harvested and analyzed for nitrogen.

\section{Management Implications}

'The land manager should know the improvement potential for each kind of land he administers. This knowledge should include the stage of deterioration when certain practices will be effective, the total and species response expected, and hydrological and wildlife considerations.

Results of this study show that an understory of Idaho fescue, bluebunch wheatgrass, or Thurber needlegrass will give a yield response when low sagebrush is controlled. The greatest response will be obtained on high-potential sites in fair condition. Since dominant grasses do not respond for 2 years after treatment, grazing should be managed accordingly. A grazing system which allows seed production, trampling to plant seed, and a non-use period should increase establishment of new plants in the interspaces. Spring grazing capacity was also increased by brush control. Therefore, treated areas could be utilized by more livestock earlier in the spring than untreated areas.

On sites in poor range condition, squirreltail gave a smaller response and the response was not obtained for 2 to 4 years after treatment. Annual species may increase rapidly the first year after treatment and can suppress the perennials. Low condition sites probably should not be treated for brush control unless some kind of intensive management can be practiced for control of annuals. Early spring use may be a tool for this purpose.

Increased density, vigor, and growth of bunchgrasses after treatment of fair condition range suggest more favorable hydrological characteristics. Treated sites would have more plants in the interspaces, more fibrous roots in the surface soil horizons, more organic matter, better soil tilth, and more herbage and basal area cover. Loss of shrub cover may be unimportant. The coppice dune beneath shrubs has a high water infiltration rate with very little runoff after brush removal (Blackburn and Skau, 1971).

Areas within the low sagebrush type are used by sage grouse (Centrocercus urophasianus) for strutting grounds, nesting, roosting, loafing, and escape cover. In addition, sage grouse are dependent upon sagebrush species and associated forbs for a major portion of their diet. Herbicidal control of low sagebrush will destroy this habitat. Therefore, to maintain sage grouse habitat, large-scale low sagebrush control projects should be joint ventures between the land management agencies and wildlife interests to select sites for treatment.

\section{Literature Cited}

Beetle, A. A. 1960. A study of sagebrush; the section Tridentata of Artemisia. Wyoming Ag. Exp. Sta. Bull. 368. 38 p.

Blackburn, W. H., and C. M. Skau. 1971. Infiltration studies on selected vegetation-soil units within 12 range watersheds in Nevada Annual Prog. Rep., Proj. 684, Coll. of Agr., Univ. of Nev., Reno. 61 p.

Chapman, Homer D., and Parker F. Pratt. 1961. Methods of analysis of soils, plants, and water. Univ. of Calif., Div. of Agr. Sci. 309 p.

ECKerT, Richard E., JR. 1957. Vegetation-soil relationships in some $A r$ temisia types in northern Harney and Lake Counties, Ore. Ph.D. Thesis, Oregon State Univ., Corvallis, Ore. $208 \mathrm{p}$.

Eckert, Riciard E., JR., AND RAymond A. Evans. 1968. Chemical control of low sagebrush and associated green rabbitbrush. J. Range Manage. 21: 325-328. 
Eckert, Richard E., JR., Gerard J. Klomp, James A. Young, and RayMOND A. Evans. $1970 . \quad$ Nitratenitrogen status of fallowed rangeland soils. J. Range Manage. 23:445-447.

Hedrick, D. W., D. N. Hyder, F. A. Sneva, AND C. E. Poulton. 1966. Ecological response of sagebrush-grass range in central Oregon to mechanical and chemical removal of Artemisia. Ecol. 47:432-439.

Hyder, D. N., and F. A. Sneva. 1956. Herbage response to sagebrush spraying. J. Range Manage. 9:34-38.

Hyder, D. N., C. E. Conrad, P. T. Tueller, L. D. Calvin, and C. E. Poulton. 1963. Frequency sampling in sagebrush-bunchgrass vegetation. Ecology 44:740-746.

Passey, H. B., and V. K. Hugie. 1962.
Sagebrush on relict ranges in the Snake River Plains and northern Great Basin. J. Range Manage. 15: 273-278.

Robektson, D. R., J. L. Nielsen, ANd N. H. BARE. 1966. Vegetation and soils of alkali sagebrush and adjacent big sagebrush ranges in North Park, Colorado. J. Range Manage. 19: 17-20.

Sneva, Forrest A., Donald N. Hyder, ANd C. S. Cooper. 1958. The influence of ammonium nitrate on the growth and yield of crested wheatgrass on the Oregon High Desert. Agron. J. 50:40-44.

Summerfield, Harry B., JR. 1969. Pedological factors related to the occurrence of big and low sagebrush in northern Washoe County, Nevada.
M.S. Thesis, Univ. of Nevada, Reno. $94 \mathrm{p}$.

Tueller, Paul T. 1962. Plant succession on two Artemisia habitat types in southeastern Oregon. Ph.D. Thesis, Oregon State Univ., Corvallis, Ore. 249 p.

U.S. DEP. OF Agr. 1970. Soil Taxonomy. Soil Survey Staff, Soil Conservation Service, Washington, D.C. $350 \mathrm{p}$.

White, E. M., And J. K. Lewis. 1969. Ecological effect of a clay soil's structurc on somc native grass roots. J. Range Manage. 22:401-404.

Zamora, Benjamin Abel. 1968. $A r$ temisia arbuscula, $A$. longiloba, and A. nova associations in central and northern Nevada. M.S. Thesis, Univ. of Nevada, Reno. 194 p. 